\title{
Freud e a fisiologia
}

\author{
ERASMO GARCIA MENDES
}

$\mathrm{O}$ U POR eXtensão, a CiÊnCIA empírica. Conta-se que dr. Sigmund Freud certa vez teria alertado seus seguidores sobre a chegada dos homens da seringa. Teria com isso chamado a atenção, simbolicamente, sobre o avanço das neurociências - em particular a neurofarmacologia - quanto ao seu empenho na busca da origem e da terapia dos distúrbios mentais fundada na ciência empírica, capaz de pôr em cheque o método que criara para o tratamento considerado não-experimental de pelo menos alguns desses distúrbios.

O tempo encarregou-se de demonstrar que a preocupação de Freud era procedente. Caberia, assim, indagar em que medida, na gênese dessa preocupação e na conscientização da ameaça, estaria o fato de ter sido o mestre vienense no início de sua carreira um cientista experimental, logo, sabedor do potencial da investigação de cunho empírico. Como é conhecido, Freud começou a trabalhar em ciência no Departamento de Fisiologia de E. Brücke na Universidade de Viena. De sua vivência no mesmo falar-se-á com maiores detalhes no fim deste artigo.

Mais conveniente se afigura tratar primeiramente do confronto, ora em foco, entre a psicanalise (PA) e as neurociências; de como os resultados destas tenderiam, segundo uma corrente de opinião, a abalar os alicerces do método freudiano de análise dos meandros da mente e seus descaminhos.

Um dos pontos de ataque certamente decorre do conhecimento de que os neurônios - unidades celulares funcionais do sistema nervoso - comunicam-se entre si preponderantemente através de mediadores químicos (neurotransmissores) que um lança no que lhe está imediatamente contíguo na região de contato (sinapse), estimulando-o ou inibindo-o a gerar o seu próprio impulso nervoso. Disso depende o funcionamento de cadeias de neurônios que, por exemplo, quando os receptores sensoriais são estimulados, encarregam-se de veicular a informação colhida até os centros nervosos de sua interpretação e seu armazenamento. De tal veiculação resulta grandemente a sensação de ser, traduzida em percepções, emoções, cognição, cogitação, memória, respostas de ajuste ao meio. Daí a emergência natural da idéia de que, de desarranjos nessa transmissão interneurônica, poderiam surgir distúrbios mentais. Tais desarranjos adviriam de alterações nas cadeias bioquímicas da síntese desses mediadores ou, eventualmente, de hormônios. 
Assim, por exemplo, no que toca à esquizofrenia, foi formulada há anos, na revista britânica Lancet, uma interessante hipótese. Nos portadores do mal, uma alteração no catabolismo da melanina, coordenado pelo hormônio epifisário melatonina, reflitiria uma anormalidade na síntese desse hormônio, cuja cadeia se interromperia, detendo-se num composto intermediário. Este seria o causador da síndrome, por se assemelhar ao alucinógeno harmalina. Assim, o esquizofrênico produziria a sua própria droga psicodisléptica. Na reunião da Associação Psiquiátrica realizada em Dallas, em 1972, informou-se que uma proteína do sangue (Alfa-2-globulina) tem, nos esquizofrênicos, sua estrutura alterada; essa alteração levaria as células cerebrais a tomar uma quantidade excessiva do aminoácido triptofano, que se transformaria facilmente no dimetil derivado (DMT), composto altamente alucinogênico. Mais recentemente, a esquizofrenia vem sendo relacionada com o excesso de produção do neurotransmissor dopamina - uma monoamina: um quadro semelhante ao da doença surge à administração de cocaina ou anfetamina, que elevam o nível e a ação desse neurotransmissor, cujos receptores cerebrais estariam aumentados nos pacientes. Outros neurotransmissores da classe das monoaminas - como a noradrenalina e a serotonina - e também o hormônio hipofisário ACTH estariam, por desequilíbrios de suas produções, envolvidos nos distúrbios maníaco-depressivos e na ansiedade. A sindrome do pânico tem sido associada a alterações metabólicas na região temporal do cérebro, parecendo dever-se à atividade anormal de um grupo de neurônios produtores de adrenalina aí situados, daí a ação terapêutica de drogas que atuam nos mecanismos adrenérgicos.

Esses poucos, porém importantes, exemplos de casos nos quais a investigação de cunho bioquímico-farmacológico demonstrou que distúrbios psíquicos podem ter causas orgânicas bastam para evidenciar o impacto que tudo isso iria causar na PA, ensejando ataques ao seu método supostamente não-científico de abordagem. Comparado com os elevados custos temporais e financeiros da prática psicanalítica, o emprego de drogas surgiria como mais rápido e menos oneroso meio de corrigir os desvios mentais devidos às anomalias na produção ou na ação de neurotransmissores.

Tais ataques não se vêm restringindo aos meios acadêmicos e já aparecem na imprensa leiga, como atestam pelo menos dois casos abordados a seguir. Quando a revista Time (6.7.92) publicou uma matéria referente à esquizofrenia e à depressão, apensou à mesma um curto artigo de J.Elson sobre o que chamou "O Eclipse de Freud". O autor, embora reconhecendo Freud como o pai da psiquiatria e um pensador revolucionário como Darwin, admitiu que, com o advento da terapia por drogas, a PA tornou-se quase irrelevante, ainda que, mesmo entre os neurofisiologistas, se aceite que as drogas agem melhor em conjunto com algum tipo de análise. Apesar de eficaz em casos de estresse diário e algumas formas de neurose, "nem o mais fanático freudiano acredita que (a PA) funcione 
em depressão profunda ou esquizofrenia". Reconheceu, porém, que o próprio Freud duvidou do êxito da PA na esquizofrenia (parafrenia, para ele), pois, no caso, a falta de interesse do paciente pelo mundo torna-o incapaz de transferência, que é a chave do processo pelo qual o paciente redireciona seus sentimentos inconscientes ao analista. Freud porém teria se excedido em sua ênfase na sexualidade como a causa radical de todas as neuroses. Mas ainda assim, admitiu, continuaria grande o impacto das idéias do mestre vienense, valendo a opinião de A.Cooper de que, em alguma medida, sem o saber todos somos freudianos, tal o grau de impregnação do qual nos achamos possuídos pelos conceitos de Freud. Assim, ao pretender expor o eclipse de Freud, Elson acabou por enaltecê-lo: foi o pioneiro na concepção do inconsciente, o primeiro a especular que os eventos traumáticos da infância podem influenciar o jeito do adulto, a postular que na PA o paciente, não o doutor, dirige a terapia, tirando este último de um papel autoritário para outro mais receptivo. Nesse sentido, todas as formas de terapia pela fala deveriam ser consideradas um legado de Freud.

Outro ataque à PA, divulgado pela imprensa não-especializada, foi o artigo de F.Crews em New York Review of Books (v. 21, n. 2,

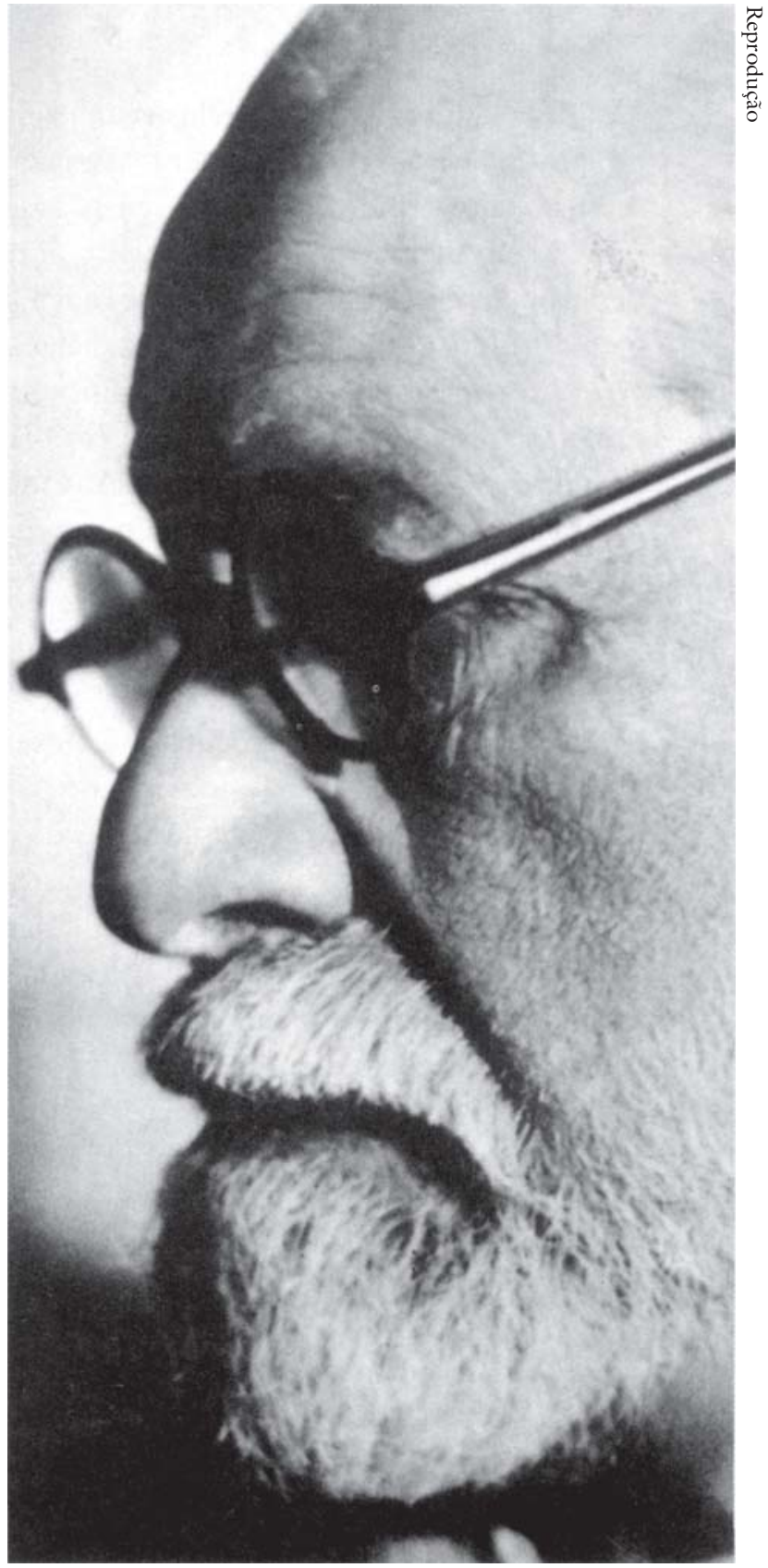

Sigmund Freud em 1935

93). Não haveria mais dúvidas de que, como forma de tratamento, a PA viria passando por um longo declínio. Embora alguns pacientes admitam que, com esse tratamento, tenham melhorado a compreensão de si mesmos e modificado sua personalidade, a PA teria sempre se mostrado de parco êxito ou ineficaz na 
remoção dos sintomas neuróticos. Um número cada vez menor de analistas a praticaria e muitos negar-lhe-iam qualquer mérito médico, em que pese o fato de ter sido esse tipo de tratamento considerado o único eficaz para o espectro de desordens "do lado de cá da psicose".

O assunto já passou inclusive às páginas de imprensa nacional e, há algum tempo, foi avivado no suplemento Mais da Folha de S. Paulo (21.11.93), sob o sensacionalista título "A Neurociência avança e ameaça invadir a praia da Psicanálise". A notícia aparecida em Science, por exemplo, sobre a descoberta do gene determinante da homossexualidade mostraria que a questão foi transferida da PA para a genética molecular. Os psicanalistas contra-atacam e, embora reconhecendo a superioridade das neurociências no tocante às psicoses, retrucam que seriam de pouca valia "no circuito cotidiano das neuroses", na decifração das intríncadas elaborações lingüísticas do inconsciente. Indiferentes a essa argumentação, as neurociências viriam progredindo na pesquisa das causas orgânicas das psicoses, neuroses e, mesmo, alterações do comportamento normal. "Do gene da agressividade à química sutil da esquizofrenia, torna-se evidente que a cabeça, afinal, faz parte do corpo".

Nesse mesmo suplemento, R. Mezan (1993) empreendeu veemente resposta ao propalado assédio das neurociências à PA. A propósito da crítica de Crews, Mezan assinalou que se tratava de exemplo de um movimento mais amplo tendente a admitir a PA como um vasto embuste; que apenas uma espécie de xiitismo ou interesses materiais sustentariam ainda a "a balela do inconsciente". Para Mezan, a questão está mal colocada, por implicar que a PA persegue uma finalidade tal como o tratamento medicamentoso: a remoção dos sintomas neuróticos. Nesse caso, perderia porque a cura visada importa em centenas de sessões com os pacientes e se baseia "numa inacreditável mistura de raciocínios circulares e premissas", se comparada com a via medicamentosa. A PA, todavia, não visaria a remover o sintoma neurótico no sentido médico, daí não haver antagonismo entre PA e neurociências, cabendo indagar como tal questão foi suscitada.

A PA, acentuou Mezan, é um método de investigação do sentido dos atos e produções psíquicas, uma teoria geral do homem baseada em estudo e forma de tratamento de problemas mentais. Nesse sentido, não é como método pouco séria, como teoria mal construída, nem como terapia inútil. Freud, vindo da ciência empírica, acreditava no caráter científico da PA por obedecer ao critério da investigação adequada.

À crítica de o objeto de PA não ser parte do mundo físico, de modo a permitir a reiteração de observações e procedimentos, Mezan retruca que, no caso, o objeto é o sujeito, pessoa singular e única, irreprodutível e inclonável, logo, insubmissível a um novo experimento em condições idênticas. O objetivo 
da PA é o inconsciente, mesmo que neurologicamente indefinido, pois perscrutável através da análise. Cada sessão com o analista é única, mas por reiteração, acaba revelando elementos constantes e o padrão característico do analisado. Assim, a singularidade é mantida não no plano de cada fala ou emoção, mas no do indivíduo, um articulado conjunto de desejos, reações e fantasias, possibilitando o surgimento do desenho do inconsciente e permitindo evidenciar traços do universo imanente, que ele partilha com os outros.

O sintoma neurótico, assinalou Mezan, não tem para a PA o mesmo estatuto que em medicina orgânica ou psiquiatria. Não é necessariamente o que o indivíduo tem na consciência, mas pode ser a total incapacidade de perceber que algo sucede com ele. O sintoma pode se apresentar como absurdo. Assim, o conteúdo de sua queixa não deve ser confundido com o sintoma, nem preocupar demasiadamente o analista, podendo não ser idêntico ao(s) seu(s) significado(s) inconsciente(s). O paciente não saberá como o sintoma sobreveio porque suas conexões com o restante da vida psiquíca foi destruído por mecanismos de defesa. Então, o paciente compensa o insucesso na busca de motivos reais como um tecido de idéias e emoções que confiram sentido ao sintoma. A tarefa do analista é descobrir e desmontar pacientemente "essas armaduras de fantasias plausíveis que nós formulamos", sem violência ou de chofre que resultem em angústia ou vazio. Daí necessariamente a longa duração das sessões, cujo ritmo é determinado pelo paciente.

Não haveria razão para incompatibilidade entre PA e neurociências. Ao contrário, neurolépticos, antidepressivos e ansiolíticos podem ajudar a PA, criando condições para a análise. Isso porque se, por um lado, um certo nível de angústia no paciente é desejável (Freud recomendava esse procedimento), por outro lado, drogas adequadas podem tirá-lo de depressão profunda, reerguendoo para o mínimo de funcionamento da mente necessário à análise. Essa seria a relação efetiva entre neurociências e PA, de colaboração eventual, tornando exdrúxula a idéia de que os progressos nas primeiras são destrutivos para a segunda.

Essa idéia, pondera Mezan, só poderia provir da confusão quanto à natureza da PA e da experiência que ela enseja, dissipável à luz da história da disciplina. Quando Freud criou a PA, não havia método algum (grifo de Mezan) para tratar do sofrimento psíquico. Freud criou a "situação analítica" dando a palavra aos pacientes sobre seus males. De acordo com os modelos vigentes na época, a disciplina foi considerada um ramo da medicina psiquiátrica, quando era muito mais do que isso, ou seja, um procedimento sui generis, operando segundo princípios próprios e objetivando a transformação da personalidade do paciente. Nesse sentido, destaca Mezan, a PA é um monumento de engenhosidade e de inteligência, um instrumento impar para a investigação dos processos mentais e emo- 
cionais, não surpreendendo que, desde o início, tenha sido perfilhada por algumas das mentes mais brilhantes e sagazes deste século.

É difícil discordar de Mezan ao colocar, sem antagonismo, a PA e as neurociências dentro de seus objetivos específicos. Sou um biólogo experimental, com trabalhos na área de transmissores em junções neuromusculares, logo, poderia estar propenso a admitir a crítica que se faz à PA, à luz das neurociências. Contudo, continuo a acreditar no método psicanalítico de perscrutar a mente por meios, diria, não-invasivos na comparação com os fisiofarmacológicos. Até me proponho uma analogia: a PA poderia estar para as neurociências como as análises telescópicas e bolométricas do relevo e da temperatura da lua estiveram para o conhecimento direto adquirido após o homem ter pisado no solo do nosso satélite. Com uma vantagem para a PA: o homem ainda está longe de pisar no solo da mente.

Até agora, o fato de alguns distúrbios nervosos virem coincidindo com desarranjos na produção e liberação de certos neurotransmissores diz ainda pouco quanto ao entendimento da mente. Cabe aos neurocientistas descobrir a sede e os mecanismos pelos quais se adquire a consciência e por que certos desejos, emoções e memórias se reprimem. Tarefa árdua, que implicará inclusive estudos de aspectos evolutivos do sistema nervoso dos vertebrados ao incorporar modificações morfo-fisiológicas geneticamente induzidas e mantidas por seleção natural, enquanto mantendo velhas estruturas eventualmente mudadas, mas ainda funcionais.

Penso primeiramente no "cérebro reptiliano" de MacLean (1972), constituído de estruturas límbicas, incapaz de se expressar via linguagem, mas implicado em processos arquipsíquicos que se associam às formas mais elementares do comportamento; reptiliano porque corresponde ao estágio filogeneticamente anterior de regiões cerebrais que, nos répteis, nos quais o neocortex é incipiente, têm funções ulteriormente transferidas ao cortex de mamíferos, retendo apenas as ligadas ao comportamento instintivo ou emocional. Assim, descargas neurais no cortex límbico, ou em suas proximidades, podem produzir amplo espectro de sentimentos emocionais, fortes elementos de convicção quanto ao que é real e importante, bem como sentimentos do tipo heureca, que se evidenciam através de um súbito dar-se conta, tais como é isso! É certo! Penso, em seguida, em Lorenz (1939) sugerindo ser o conhecimento inato uma retenção em estruturas nervosas de experiências vividas em etapas pregressas da Evolução, capazes de gerar no homem conceitos a priori, intuitivamente óbvios, como tempo, espaço e causalidade.

Em outra linha de esforços para penetrar nos escaninhos da mente, recordaria os experimentos de Penfield (1959) sobre o cortex interpretativo, em que se demonstra que respostas experienciais (reencenação visual ou auditiva de even- 
tos passados) ou respostas interpretativas (sensação do tamanho de objeto ou intensidade de som; euforia ou angústia súbita) podem ser evocadas por estimulação de regiões do lobo temporal durante cirurgias em que o cérebro fica exposto. Desses e de outros experimentos deriva a sugestão de os eventos da mente poderem estar gravados em fitas neurônicas que, como disco de um fonógrafo, podem ser acionadas para evocar o passado, dimensionar as sensações, conhecer e cogitar (recorde-se que, da combinação desses conhecimentos com a PA, E.Bern criou a sua Análise Transacional). Ou, ainda, relembrar os experimentos de ablações feitos no lobo frontal por Fulton e colaboradores (Crawforf et al., 1948), com as macaquinhas Becky e Lucy, em que uma neurose experimental, gerada por frustrações diante da impossibilidade de resolver uma situação dada, praticamente cessou, passando os animais a encarar mais filosoficamente os seus fracassos. Foi essencialmente esse tipo de experimento que levou Egas Moniz a investigar os efeitos de leucotomia frontal em paciente humanos com ansiedade, o que lhe valeu o Prêmio Nobel (Moniz, 1936).

Todos esses eventos servem como alguns marcantes exemplos do empenho das neurociências em sondar, num sentido reducionístico, a mente, objetivando encontrar substrato morfo-fisiológico para ela. Empenho natural num biólogo experimental que, embora podendo admitir a mente como um epifenômeno, um fato emergente, da maquinaria nervosa, não se furta à tentação de analisar esta última em termos de seus componentes. Esse empenho, todavia, não invalida o da PA em investigar a mente através do que chamaria "sondagem anamnésica", como meio de extrair de um paciente sentimentos que, reprimidos, causam distúrbios. A admissão de que esses sentimentos se originam num plano dito inconsciente não torna a hipótese uma balela, nem o inconsciente uma figura de retórica, pois que a concepção deste último tem coerência especulativa e vem embasando psicoterapia de sucesso. Caberia, sim, às neurociências subsidiar experimentalmente essa concepção, tentando desvendar onde, no contexto do sistema nervoso, cria-se esse plano inconsciente, se é que se trata de um só plano ou da intersecção de vários planos funcionais nervosos. Acontece que essas intersecções sequer são suficientemente conhecidas para explicar o consciente.

Nesse sentido, após décadas de recusa da idéia de que a atividade mental possa ocorrer de forma não consciente, o inconsciente está de novo sendo levado a sério, como uma parte muito maior da vida mental do que mesmo Freud imaginou. A mente inconsciente, admite-se agora, compreenderia e reagiria a significados, formaria reações emocionais e guiaria a maior parte das ações de modo grandemente independente com relação à percepção consciente. As evidências se estenderiam além dos laboratórios, chegando a situações da vida real. Apesar da experiência subjetiva de se estar com o controle consciente dos sentimentos e dos pensamentos, das decisões e das ações, as pessoas seriam muito mais dirigidas 
pelo que sabem através da mente inconsciente. Segundo E.Donchin (Laboratório de Psicologia Cognitiva da Universidade de Illinois), até 99\% da atividade cognitiva seriam inconscientes. Os métodos que vêm conferindo uma nova respeitabilidade ao inconsciente são estritamente científicos: isola-se um pequeno detalhe do comportamento, que é experimentado sob condições rigorosamente controladas. A.Marcel (Cambridge) entrou no campo da percepção não-consciente ao estudar a leitura por crianças de palavras rapidamente projetadas numa tela e apenas vistas de relance. Quando o significado da palavra não pode ser conscientemente entendido, as crianças às vezes "chutavam" uma palavra de significado semelhante, por exemplo, "rainha" em vez de "rei". Esse "engano inteligente" indicou uma leitura inconsciente e, para Marcel, "assim que aprendemos a ler os significados das palavras podem ser registrados sem a consciência... uma boa parte da percepção é automática e independente da intenção consciente". Ainda sobre o inconsciente cognitivo, o meu colega de departamento e especialista em memória, Gilberto F. Xavier, chamou-me a atenção para um relativamente recente trabalho de Kihlstrom (1987). Nele o modelo clássico informação-processamento da cognição humana é revisto criticamente e considerado como deixando pouco lugar para a investigação do inconsciente. Sua substituição por modelos do tipo ACT (Adaptative Control of Thought) ou PDP (Paralled Distributed Processing) leva a considerar ser inconsciente quase todo o processamento da informação, inclusive as funções mentais superiores envolvidas na linguagem, na memória e no pensamento. O inconsciente é concebido como identificado com processos de memória procedimental e/ou memória declarativa do tipo semântico.

Mas não é apenas das neurociências que procedem os ataques à PA, pois, nos círculos filosóficos ela também já foi posta em cheque, como atesta o livro de Gilles Deleuze e Felix Guattari, O Anti-Édipo (traduzido pela Imago, 1974), cujo conteúdo conheço somente pelas suas repercursões. A revolução freudiana teria encerrado seu ciclo, atingida pela inexorável aceleração da História. Todas as suas inovações, do complexo de Édipo à revelação das pulsões, apareceriam agora como opressiva barreira à livre floração da personalidade; da PA, que deveria ser um canto de vida, emanaria um canto de morte. Freud teria limitado como libido a descoberta de uma essência objetiva e vital do desejo mas a indicação do instinto de morte teria privado a sexualildade do seu papel motor, ao menos num ponto capital, a gênese da angústia, que poderia se tornar a causa autônoma do recalcamento sexual. Daí que a sexualidade animaria mais uma crítica social da civilização, a única instância capaz de opor-se ao desejo de morte. A PA nos colheria numa rede constrangedora, tecida de um edipianismo difuso, que desfiguraria e mistificaria a vida - da criança ao adulto - gerando problemas neuróticos. Édipo seria antes uma idéia do paranoico adulto que um sintoma infantil do neurótico; antes literário que psicanalítico. A PA esbarraria na Etnologia e a crença num Édipo africano ou índio seria uma forma refinada de colonização, 
por estar a psicanálise umbelicalmente unida à ordem burguesa. O triângulo PaiMãe-Édipo seria ardilosa e nauseante cela de aprisionamento do neurótico, sufocando toda a sexualidade como produção de desejo, reduzindo-a a um pequeno segredo sujo. Esses filósofos (Guattari era também psiquiatra) definem o homem como uma máquina desejante, propondo uma esquizo-análise simultânea dessas máquinas desejantes e dos investimentos sociais por elas feitos. $\mathrm{O}$ inconsciente não seria o teatro do drama edipiano, mas antes uma usina; lugar de produção que não se preocupa com o sentido, mas com o uso. Aí se encontraria a verdadeira questão do desejo, cuja equação articularia a esquizofrenia, limite absoluto de toda a sociedade com o capitalismo, limite relativo da mesma. Transgressãoculpabilidade-castração não seriam estruturas do inconsciente, mas forças usadas pela PA para edipianizá-la.

Como teria reagido Freud a essa crítica? Por mais reticente que tenha se tornado, pouco antes e nos primeiros anos de universidade com relação à filosofia e àqueles que a ela se teriam rendido "por desespero", Freud dedicou-se bastante à disciplina para ampliar a sua cosmovisão. Mas, é sintomático, como assinala Peter Gay na sua magnífica biografia de Freud (Gay, 1989), ter sido Feuerbach o filósofo que leu com maior proveito, o qual chegou a negar à sua atividade filosofante o nome de filosofia e se considerar "um pensador intelectual da natureza”. Feuerbach repudiava abstrações áridas, considerando obrigação desmascarar a teologia que, a seu ver, deveria estar na Antropologia. Não sendo propriamente um ateista, sua doutrina e seu método levavam ao ateismo. Era quase tão crítico com relação à maior parte da filosofia quanto à teologia. Tudo isso agradava Freud, mas não obstou que ficasse certo tempo sob a influência das idéias de Brentano, adepto de Aristoteles e da psicologia empírica, a um só tempo crente em Deus e no darwinismo. Nessa ocasião chegou a se considerar momentaneamente um não-materialista, para, logo mais, declarar-se "um estudante de medicina ateu e empirista". Datam dessa época (1875-76) os rumos imeditamente posteriores da carreira de Freud na Universidade de Viena, caracterizados pela adesão ao empirismo como forma de indagação científica. Sua atividade nesse período, como ressalta P.Gay, esteve inicialmente voltada para os aspectos básicos das ciências naturais (em particular a biologia) e, aos poucos, evoluiu para uma psicologia que ele queria experimental e, daí, para a PA.

Ao ter que se decidir por uma carreira universitária, Freud pensou primeiro em Direito. Mas a doutrina de Darwin continuava a atraí-lo fortemente pela promessa de um enorme avanço na compreensão do mundo. Uma conferência de Carl B. Brühl, docente de anatomia comparativa e zoologia na Universidade, acerca de um ensaio de Goethe ("Sobre a Natureza") acabou por demovê-lo do curso escolhido em favor de outro mais diretamente ligado às ciências naturais. O fragmento do ensaio que impressionou Freud celebrava a Natureza "erotizada como uma mãe envolvente" e, segundo Wittels, seu primeiro biógrafo, o lugar 
que ele ocupou na vida de Freud pareceu implicar "uma recordação encobridora, uma invocação de atributos maternos de afeto, calor e nutrição, transferíveis à natureza". Decidira-se então (1873) tornar-se cientista natural.

Por que teria finalmente escolhido Medicina? Porque, acentuou Gay, a natureza que mais avidamente queria conhecer era a humana, sua ânsia de saber era mais voltada para assuntos humanos, a sua mente já estava cheia de ousadas curiosidades e percepções psicológicas, prenunciando a busca futura de revelações mais profundas. Assim, embora tivesse livremente escolhido medicina, não o fizera pelo que o status de médico lhe proporcionaria, senão porque

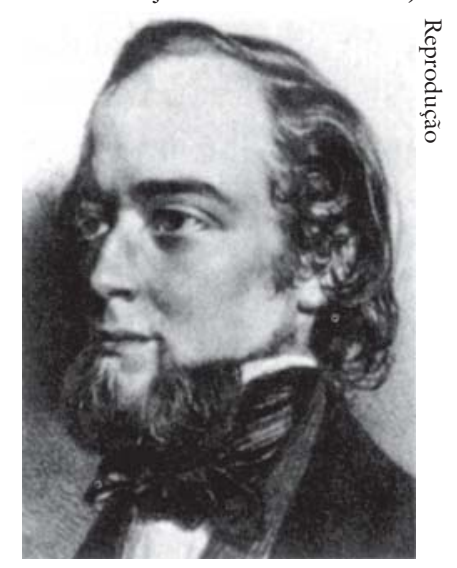

Carl Brühl os estudos médicos na época eram os que também iriam lhe propiciar saciar sua sede de conhecimentos científicos gerais, em particular os biológicos, adestrando-o nos métodos de observação e experimentação. Mas no $3^{\circ}$ ano do curso de medicina ainda lhe restavam preocupações filosóficas; fascinado pela zoologia, matéria básica complementar do curso, pensou antes num doutorado nessa disciplina do que em medicina. Ao final, esta última prevaleceu, como forma de "não abraçar a amorosa e sufocante mãe natureza". Medicina, todavia, de cunho experimental, tornando-se seu desejo ter um laboratório com todo o equipamento necessário à pesquisa. A aventura do Beagle ainda o encantava e almejou ter um navio oceanográfico. Num retrospecto, em 1927, não se reconheceu propriamente um médico e, em 1935, mapeou o "desenvolvimento regressivo" que seguira, depois de um "desvio durante toda uma vida pelas ciências naturais, medicina e psiquiatria", para voltar a "aqueles problemas culturais que outrora haviam fascinado o jovem que mal despertara para o pensamento".

O momentâneo interesse pela zoologia deveu-se a que, na Universidade, foi aluno e trabalhou depois com Carl Claus, vindo da Alemanha para chefiar o Instituto de Anatomia Comparativa. Nesse tempo, Freud empreendeu uma viagem à Inglaterra, onde travou conhecimento com as obras de Tyndall, Thomson, Huxley e Lyell, interessando-se pela polêmica entre empirismo e metafísica. No regresso a Viena, Claus enviou-o à Estação de Biologia Marinha, que fundara em Trieste, onde Freud estagiou duas vezes em 1876. Sua incumbência era confirmar ou não a existência de testículos na enguia proposta por S.Syrski, assunto con-

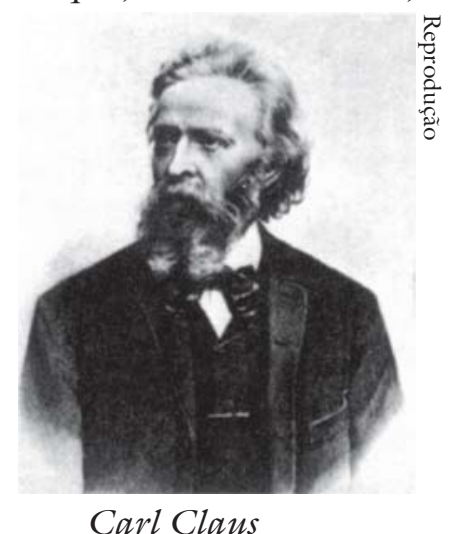

Carl Claus troverso, implicando hermafroditismo nesse peixe. Data dessa época o primeiro trabalho científico de Freud ("Observações sobre a forma e a microestrutura dos 
órgãos lobados da enguia, comumente descritos como testículos", publicado em 1877 nos SA Akad, Wien). Todas as enguias dissecadas foram fêmeas, mas a pesquisa iniciou Freud na metodologia científica e, segundo alguns, a busca de testículos no peixe poderia ter despertado seu primeiro interesse por estudos sobre a sexualidade. Contudo, por alguma razão (uma dose obscura de antipatia, propõe P.Gay), Freud se afastou de Claus, que não figura nos seus escritos autobiográficos.

O mentor seguinte, na universidade, foi o grande fisiólogo Ernst von Brücke, em cujo laboratório Freud encontrou plena satisfação, admirando e pro-

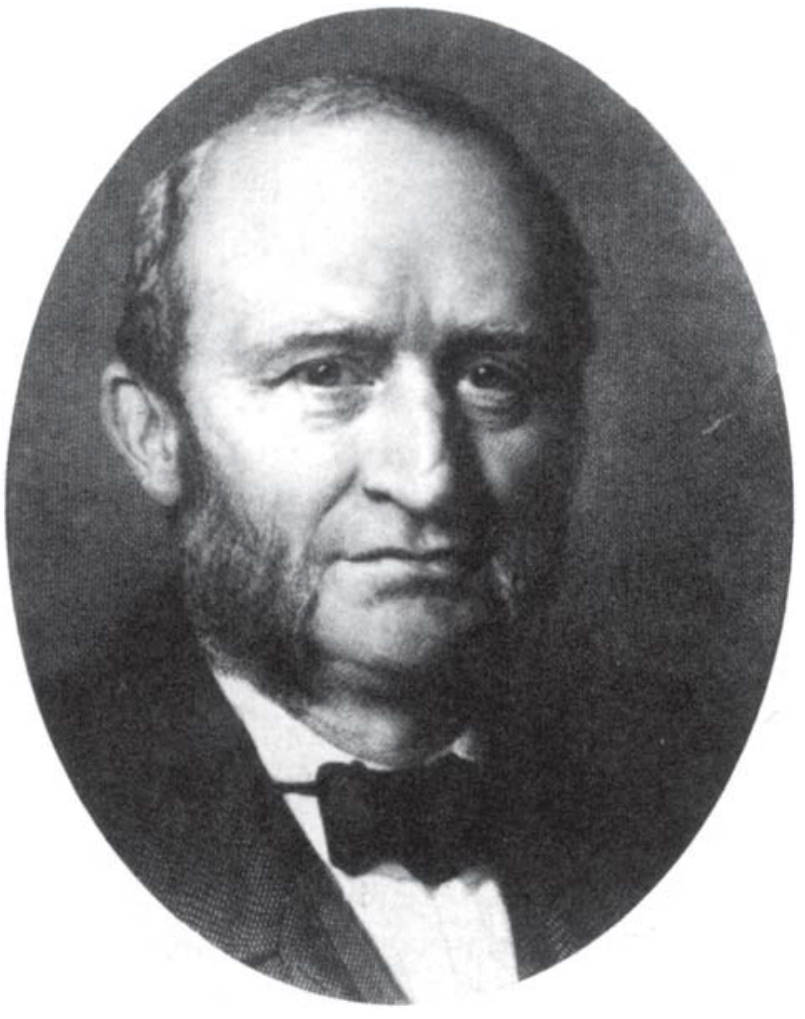

Ernst von Brücke curando imitar o mestre. Aí conheceu Josef Breuer, 15 anos mais velho e já renomado neurólogo (por ter descrito, juntamente com E.Hering, o reflexo respiratório que leva o nome dos dois). Breuer iria, como se sabe, trazer a Freud a sua primeira paciente (Ana $\mathrm{O}$, caso fundador da PA). Entre 1876 e 1885, Freud ocupou-se de questões de neurofisiologia comparativa, disso resultando o seu segundo trabalho científico ("Sobre a origem da raiz nervosa posterior na medula de Ammocoetes" - larva do peixe lampréia, também publicado nos SA Akad, Wien, 1878) e depois estudos sobre o sistema nervoso do lagostim. Preferia, então, esse tipo de investigação ao tratamento de pacientes, atribuindo-se a isso o fato de ter levado oito anos (em vez de cinco) para se formar em medicina, fascinado que estava pela pesquisa de cunho desinteressado. Teria mesmo sido advertido por Brücke para que prosseguisse nos estudos.

Brücke foi e continuou a ser para Freud a "maior influência que agiu sobre mim". Sua adesão à concepção de ciência de Brücke teria resistido à sua passagem das explicações fisiológicas das ocorrências mentais às explicações psicológicas, como salienta P.Gay, ainda que tenha aplicado os princípios do mestre como este jamais imaginaria. Durante seis anos trabalhou no laboratório de Brücke, resolvendo problemas que o mestre lhe colocava, inicialmente com peixes e crustáceos e, a seguir, com seres humanos. 
O positivismo, como filosofia de ciência para Brücke foi, para Freud, segundo P.Gay, tão formativo quanto o profissionalismo do mestre. O positivismo adotado refletia menos uma escola organizada de pensamento que uma atitude difusa com relação ao homem, à natureza e ao método de investigação. Havia a esperança de que o programa das ciências naturais, suas descobertas e seus métodos seriam transferíveis à investigação de todo o pensamento e de toda a ação humanos. Nascido no Iluminismo do século XVIII, rejeitando grandemente a metafísica, o positivismo prosperara no século seguinte com os progressos da astronomia, física e química e repercussões na biologia. Em Viena, Brücke era seu representante mais eminente.

Brücke viera da Alemanha e, nos anos 40 do século em curso, ligara-se desde os tempos de estudante ao colega Emil Du Bois-Reymond para a rejeição de qualquer panteismo ou misticismo com relação à natureza, qualquer invocação de força divina ou vital para explicar o funcionamento dos seres vivos. Aos dois juntaram-se posteriormente H.Helmholtz, esse genial misto de físico e fisiologista, e Carl Ludwig para, numa reunião em Berlin (1847), nas palavras deste último, "imaginarem que deveriam constituir a fisiologia numa base físico-química e dar-lhe um lugar científico igual ao da física", ainda que "a tarefa tenha se demonstrado muito mais difícil do que anteciparam"(Gay,1989).

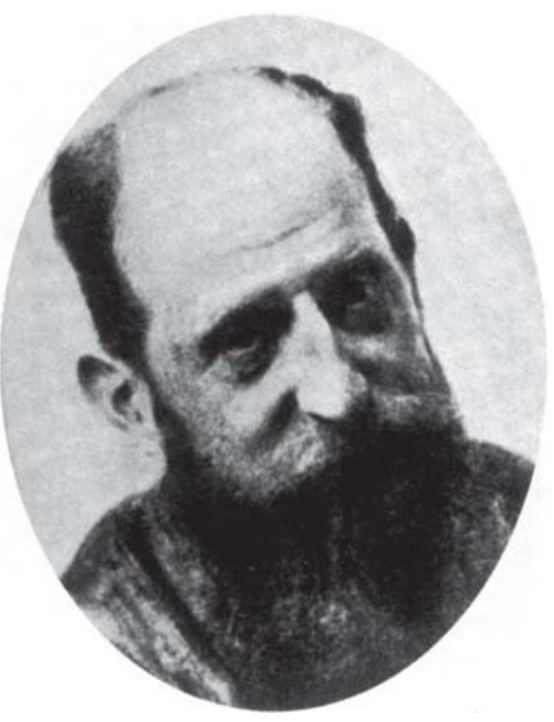

Josef Brener

Freud não ficou alheio ás repercursões da reunião de Berlin e teve mesmo a intenção, frustrada, de ir a essa cidade para assistir conferências de Du BoisReymond e Helmholtz. Este se tornara outro de seus idolos. Mas ouviu Brücke em suas "Conferências sobre a Fisiologia" (1876), nas quais enfatizava o positivismo médico. Para Freud, Brücke e seus colegas tinham se tornado os herdeiros da filosofia, cujas concepções encontravam forte apoio na obra de Darwin, num tempo em que a teoria da seleção natural era ainda controversa. Darwin se encarregara de situar o homem no reino animal, surgido por causas que operaram transformações na ordem natural do seres vivos, sem necessidade de se remeter a uma divindade. Como acentuou P.Gay, Freud, sucessivamente zoólogo, fisiologista e psicólogo, esteve sempre no mesmo empreendimento. Ao estudar comparativamente o sistema nervoso, Freud participou do esforço coletivo de demonstrar os caminhos da Evolução, daí ter sido o naturalista inglês para ele sempre o "grande Darwin". Comprovou processos evolutivos nas estruturas nervosas de peixes e os seus trabalhos na época formariam o primeiro elo da cadeia de idéias que em 1885 levariam ao esboço de elaboração de uma psicologia científica. 
A intenção de Freud, nessa elaboração, era "guarnecer uma psicologia natural-científica, isto é, apresentar os processos psíquicos como estados quantitativamente determinados de partículas materiais especificáveis e assim tornar esses processos descritivos e coerentes". Queria mostrar como o mecanismo mental funciona, propondo metáforas mecanicistas. Nunca abandonou a idéia de uma psicologia científica. No seu último ano de vida, ainda afirmava que a ênfase sobre o inconsciente na PA capacitava-a a "ocupar um lugar como uma ciência natural". Avançou inclusive a idéia de que, no futuro, a psicanálise poderia "exercer uma influência direta através de substâncias químicas específicas, sobre as quantidades de energia e sua distribuição no aparelho mental", à sua maneira admitindo a importância da neurofarmacologia no tratamento dos distúrbios mentais.

Em outras atividades científicas, Freud chegou a especular sobre os modos pelos quais as células nervosas funcionam como uma unidade, perdendo a oportunidade da formulação da concepção do neurônio para Waldeyer (1891). "Não foi a única vez", comentou E.Jones, "que Freud perdeu por estreita margem a fama mundial... por não ousar seguir seu pensamento até sua conclusão lógica". Outra chance perdida foi a da descoberta e da recomendação da cocaina como anestésico local e estimulante do sistema nervoso. Freud se interessara pela droga ao ler um artigo do químico Merck e ao ouvir de um médico militar relato sobre o alívio que seu emprego causava. Assim, tentou usar cocaina em pacientes cardíacos ou com esgotamento nervoso e publicou um artigo sobre a droga no Centralblatt für die gesamte Therapie (1884). Em setembro desse ano foi visitar a noiva (Martha Bernays) na Alemanha, não sem, antes de partir, ter recomendado a droga ao oftalmologista L.Königstein. No regresso a Viena verificou que, não Königstein, mas C.Koller, a quem também falara sobre os efeitos da cocaina, fizera experimentos com ela, relatados num congresso de oftalmologia em Heidelberg. Embora amargurado, Freud reconheceu a prioridade de Koller. Passou a utilizar a droga para controlar seus estados depressivos intermitentes. Sua defesa da cocaina como panacéia para dor, esgotamento, desânimo e até o vício da morfina mostrou-se infelizmente descabida. Como descabida se tornou a afirmação de Oliver Wendell Holmes quando, ao rejeitar os excessos medicamentosos da sua época, ressalvou a morfina, tida para ele como "prescrita por Deus" (Rocha e Silva, 1973).

Tendo-se em vista os anos com Brücke e a influência que este exerceu sobre Freud, dificilmente se poderia admitir que, nos longos anos em que construiu a PA, ele tivesse esquecido ou sequer menosprezado sua fase "empirista", em que trabalhou dentro de rigorosos padrões (para a época) da ciência experimental. Mesmo a transição para a PA não ocorreu sem a passagem por estados intermediários de contato com a medicina experimental. Na Universidade de Viena trabalhou, a seguir, com H.Nothnagel, professor de doenças internas (e, 
com Brücke, os seus primeiros defensores) e, depois, com T.Meynert, psiquiatra e anatomista cerebral de grande renome, com quem viria a entrar em conflito. Meynert havia impressionado Freud, quando este ainda era estudante, por sua obstinação em criar uma psicologia científica que considerasse a mente como obedecendo a uma ordem oculta à espera de um analista. O conflito surgiu por questões referentes à hipnose e à histeria. Essas duas questões levariam Freud a Paris, em 1885, para estagiar com Charcot na Salpêtrière. Freud admirava em Charcot sua admissão de que "a teoria não impedia os fatos de existirem como fonte e servidores dela". Continuou aceitando que, em matéria de ciências naturais, "sempre e apenas a experiência e nunca autoridade sem a experiência é que apresenta a decisão final". Charcot foi para Freud um "segundo Brücke", a despeito de ter acabado por divergir do mestre, o qual admitia que a hipnose somente poderia ser praticada em histéricos.

Seria impossível - e nem foi essa a intenção deste já longo artigo - esboçar a trajetória ulterior de Freud no sentido da PA. Procurei ficar nos primeiros anos de sua vida acadêmica. Uma recente visita a Berggasse 19, a longa e última sede de trabalho de Freud em Viena, onde está significativa parte do acervo do mestre, mostrou-me a importância dos personagens desses anos. Aí ocupam posição de destaque, com suas fotos, Brühl, Brücke, Claus, Breuer, Nothnagel, Meynert. O famoso divã ( $R$ uhebett), todavia, está em Londres, informaram-me, onde Freud se exilou em 1938.

Referência bibliografia

CRAWFORD, MP; FULTON, JF; JACOBSEN, CF \& WOLF, JB. Frontal lobe ablation in chimpanzee: a resumé of "Becky" and "Lucy". ARNMD, n.27, p.3-58, 1948.

FULTON, JF. Physiology. Clio Medica. N.York, PB Roeber, 1931.

GAY, O. Freud: uma vida para nosso tempo. São Paulo, Cia das Letras, 1989.

KIHLSTROM, J.F. The cognitive uncounscious. Science, n.23, p.1445-1452, 1987.

LORENZ, K. Vergleichende Verhaltsversuche. Zoologischer Anzeiger, n.12, p. 69-102, 1939.

MACLEAN, P. B. Cerebral evolution and emotional processes: new findings on the striatal complex. Annals of the New York Academy of Sciences, n.193, p.137-149, 1972.

MEZAN, R. Cada disciplina com seu objetivo. Suplem. Mais, Folha de S. Paulo, 21 nov. 1993.

MONIZ, E. Tentatives opératoires dans le traitment des certaines psychoses. Paris, Masson, 1936. 
PENFIELD, W. The interpretive cortex. Science, n.129, p.1719-1725, 1959.

ROCHA E SILVA, M. Fundamentos da Farmacologia e suas aplicações à terapêutica. v. 1, São Paulo, Edart, 1973.

Resumo

A experiência de Freud no início de sua carreira em Viena, no campo da ciência empírica, é revista e admitida como ainda relevante nos anos em que a psicanálise foi desenvolvida. Freud foi sucessivamente zoólogo (com Claus), fisiologista (com Brücke) e psicólogo (com Meynert) antes de criar a psicanálise. Por isso, teria pressentido que o avanço das neurociências e da terapia por drogas poderia conflitar com a sua terapia pela fala. A compatibilidade entre a psicanálise e as neurociências, tal como defendida por Mezan, é reconhecida em termos dos objetivos específicos de cada uma. Exemplos do empenho em explicar mecanicamente a mente são evocados, bem como a recente revalorização da concepção do inconsciente cognitivo. A posição de Freud com relação à filosofia é brevemente abordada, com menção de sua visão quanto ao positivismo. Frustrações de Freud - as chances perdidas de conceber o neurônio e de indicar o uso da cocaina - são recordadas. Em que pese a teorização implicada na psico-análise, Freud teria se mantido residualmente um cientista natural, como se proclamou um dia.

\begin{abstract}
Freud's experience in the field of empirical science, at the beginning of his carrer in Vienna, is reviewed and admitted as still relevant in the years in which psychoanalysis was developped. Freud was successively zoologist (with Claus), physiologist (with Brücke) and psychologist (with Meynert) before creating his talk therapy. This would have enabled him to forecast that the advances in neurosciences and drug therapy might conflict with psychoanalysis. The compatibility between neurosciences and psychoanalysis, as defended by Mezan, is emphasized, in terms of each having its own purpose. Exemples of efforts to explain mechanistically the mind are evoked, as well as the recent revival of the concept of cognitive unconscious. Freud's position in relation to philosophy is briefly approached, as well as his view towards positivism. His frustrations - the lost chances of conceiving the neurone and prescribing cocain - are remembered. In spite of the theorization implicated in psychoanalysis, Freud remained residually a natural scientist, as he once proclaimed himself.
\end{abstract}

Erasmo Garcia Mendes é professor titular aposentado de Fisiologia Animal e professor emérito do Instituto de Biociências da Universidade de São Paulo. É integrante da Mesa Editorial de ESTUDOS AVANÇADOS.

Estudos AvanÇAdOS 10 (27), 1996 